\title{
The endocrine polypeptide cells of the human stomach, duodenum, and jejunum
}

\author{
A. G. E. PEARSE, I. COUlling, B. WEAVERS, AND S. FRIESEN1 \\ From the Department of Histochemistry, Royal Postgraduate Medical School, London
}

SUMMARY Thirty specimens of stomach, duodenum, and jejunum, removed at operation, were examined by optical microscopical, cytochemical, and electron microscopical techniques. The overall distribution of four types of endocrine polypeptide cell in the stomach, and three in the intestine, was determined. The seven cell types are described by names and letters belonging to a scheme for nomenclature agreed upon at the 1969 Wiesbaden conference of gastrointestinal hormones. The gastrin-secreting $\mathbf{G}$ cell was the only cell for which firm identification with a known hormone was possible. Although there was wide variation in the distribution of the various cells, from one case to another, striking differences were nevertheless observable, with respect to the $G$ cell, between antra from carcinoma and from ulcer cases.

This study was undertaken with a view to establishing the overall topographical distribution of the various types of endocrine polypeptide cells in the human stomach and upper intestine. Adequate sampling was regarded as a prerequisite in view of the known variability in distribution of one of the cell types (enterochromaffin, EC) between one case and another. For this reason, suction biopsies were not used and the work was carried out entirely on specimens removed at operation. It was realized that 'normal' controls would not be available, but samples were obtained from cases without primary involvement of the stomach or duodenum.

A secondary objective of the work was the correlation of individual cell types, identified by electron microscopy, with their cytologically or cytochemically identifiable counterparts in the optical microscope.

At the outset, a problem was presented by the existence of many different terminologies and classifications of endocrine cells in the gastrointestinal tract. Until we were reasonably sure of our identifications we used a private descrip-

Received for publication 24 February 1970.

'On leave from the Department of Surgery, University of Kansas Medical School. tive shorthand terminology. Correlation with the terminology used by Solcia, Vassallo, and Capella (1969b) and by Vassallo, Solcia, and Capella (1969) had to be equated, if possible, with the scheme used by Forssmann, Orci, Pictet, Renold, and Rouiller (1969). Before the Merck conference on the 'Origin, chemistry, physiology and pathophysiology of the gastrointestinal hormones', held in October 1969 in Wiesbaden, only incomplete agreement could be reached between the three groups working in Pavia, Geneva, and London. At this meeting the provision of a common terminology was discussed and, finally, an agreed version was produced. The Wiesbaden terminology which we use throughout this paper is given in the Table, but its further discussion may be postponed until after the presentation of our results.

In parallel with this study, immunofluorescence techniques using antihuman gastrin 2-17 were undertaken on samples of pyloric antrum from different species, including man. The results with porcine antrum have already been reported (Bussolati and Pearse, 1970), and those derived from work on human antrum are the subject of a further communication (Pearse and Bussolati, 1970). 


\section{Material and Methods}

Our material consisted of surgical specimens of stomach, duodenum, and jejunum from 23 cases of gastric carcinoma, duodenal ulcer, or chronic pancreatitis, from five cases of chronic pancreatitis in which only pancreas and jejunum were available for study, from one case of carcinoma of the common bile duct, and from one case of cholelithiasis. The site from which the material was taken was identified, by letter and number, according to the plan shown in Figure 1. In five cases samples were taken from one or two areas only but in the remaining cases we were able to prepare long, thin strips of mucosa, separated from the muscularis. These were rolled up into coils, or 'swiss rolls', whose average length was $9 \mathrm{~cm}$, before fixation in the appropriate fixatives. Our swiss roll preparations usually covered two zones, ie, D1-S1, S3-S5, and S2-S4. Altogether 22 twin-zone preparations were examined, amounting to a total length of over 2 metres of mucosa.

The basic preparations were five:

(1) Swiss rolls, and shorter samples, fixed in glutaraldehyde-picric acid (Solcia, Vassallo, and Capella, 1968a). These were used for the masked metachromasia and alkaline diazonium techniques, and for various silver methods.

(2) Samples from as many numbered regions as possible were fixed in formol-ammoniumsucrose or in cold formol-calcium. These were used for enzyme histochemistry, for immunofluorescence studies, and for lead haematoxylin staining (Solcia, Capella, and Vassallo, 1969a).

(3) Small samples, from as many numbered regions as possible, were freeze-dried at $-40^{\circ} \mathrm{C}$

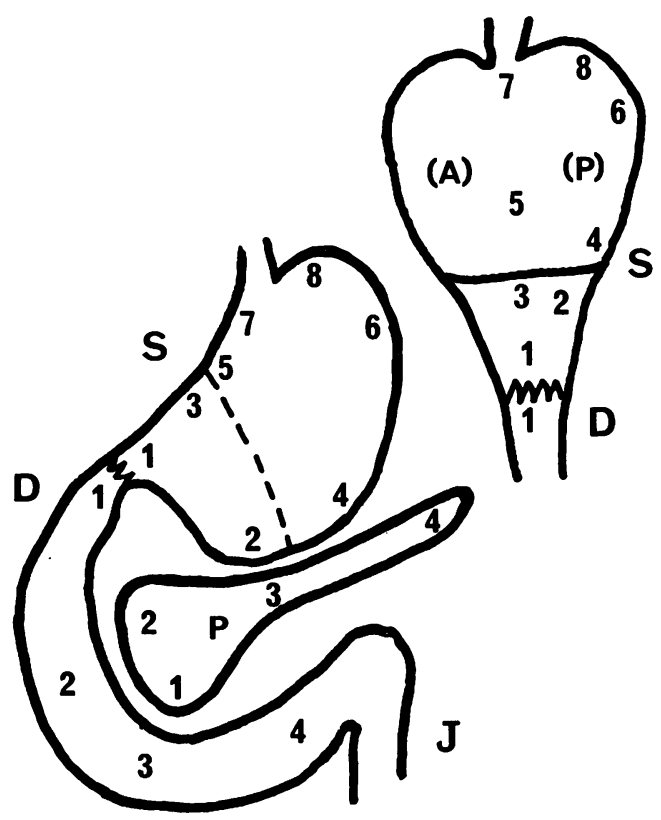

Fig. 1 Localization of samples by numbered areas. in a thermoelectric freeze-dryer (Edwards High Vacuum Ltd) and embedded in paraffin wax. These were used for immunofluorescence studies.

(4) Very small samples from the same numbered regions were fixed in glutaraldehyde, postfixed in osmium tetroxide and embedded in araldite. Thick $(0.5 \mu \mathrm{m})$ sections were stained with toluidine blue and examined by optical microscopy. Thin sections were usually counterstained with lead citrate and uranyl acetate, and examined in an AEI EM 6B electron microscope.

(5) In selected cases small pieces of mucosa, cubes of less than $1 \mathrm{~mm}$ were incubated in continuously oxygenated Tyrode's solution containing $50-100 \mu \mathrm{g} / \mathrm{ml}$ of L-dihydroxy-phenylalanine (L-DOPA), according to the procedure recommended by Håkanson, Lilja, and Owman (1969), for one to two hours. Control pieces were incubated in Tyrode's solution alone and all specimens were thoroughly washed, after incubation, in cold $\left(4^{\circ}\right)$ Tyrode's solution for two to three hours.

The following staining techniques were used routinely: masked metachromasia (Solcia et al, 1968a), Masson-Hamperl silver, and alkaline diazonium (Pearse, 1960). As occasion demanded other techniques, including Bodian protargol, and Grimelius (1968) and Davenport's silver (Hellerstrøm and Hellman, 1960), were used. In the masked metachromasia method we used, routinely, $0.2 \mathrm{~N} \mathrm{HCl}$ at $60^{\circ} \mathrm{C}$. The duration of acid treatment varied from a few minutes up to 14 hours.

\section{Results}

GASTRIC MUCOSA

We found four distinct cell types in the human stomach by electron microscopy and three by cytological and cytochemical methods. The predominant cell in the antrum was a large round or oval cell giving a purple to violet metachromasia with the toluidine blue technique (Fig. 2). Often this staining was very weak by contrast with that of the other types present in the antrum. This cell stained strongly by the lead-haematoxylin (Pb-H) method (Fig. 3) unless it was degranulated, as was commonly the case. Using the silver method of Grimelius (1968) the cell was shown to be argyrophilic.

The large predominant endocrine polypeptide cell of the antrum was found mainly in the neck region of the gland, tailing off in number towards the base. In some cases a wide band of the cells occupied the mid-zone of the glands, extending through the whole length of the sample. Cells of the predominant type were confined, almost absolutely, to the pyloric antrum (S1, $2,3)$ but we were usually able to find a few in samples of mucosa from fundic regions. In only one case did we find any of these cells in the duodenum. 


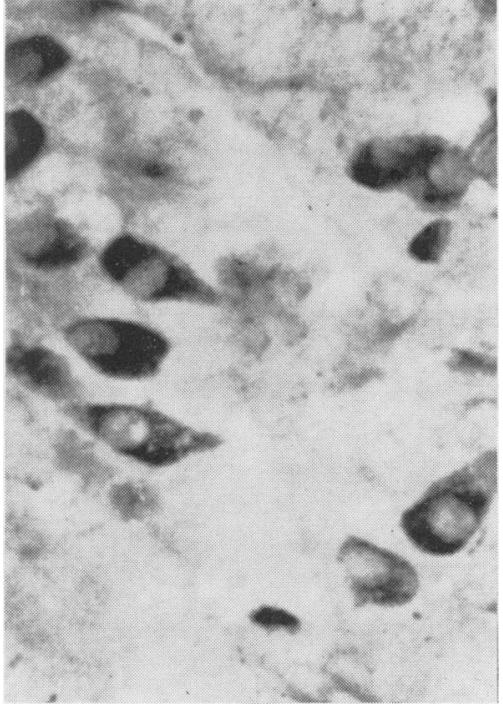

Fig. 2 Case 1: carcinoma of the stomach. Glutaraldehyde-picric-acid-fixed tissue from region $S 1$. Shows masked metachromasia in $G$ cells. Toluidine blue, $\times 590$.

We considered, using the same arguments as those of Solcia, Vassallo, and Sampietro (1967), that the distribution of the cell was such that it should be regarded as the gastrin-secreting $\mathrm{G}$ cell. It appeared to correspond to the predominant mid-zone cell of the porcine antrum which was

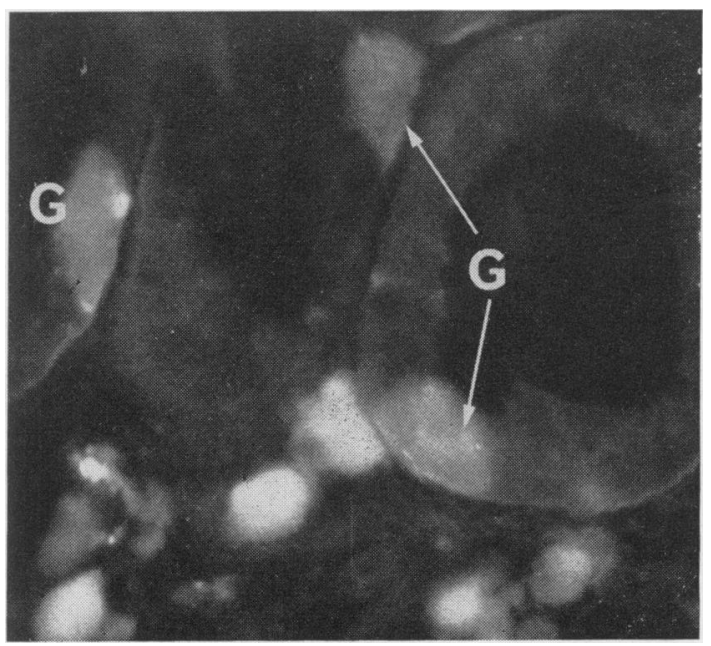

Fig. 4 Case 5: carcinoma of the stomach. Tissue from region $S 2$, incubated in Tyrode's solution containing L-DOPA for two hours, freeze-dried, and treated with formaldehyde vapour at $70^{\circ} \mathrm{C}$ for two hours. Shows green (dopamine) fluorescence in three $G$ cells within three individual glands. Fluorescent cells in the lamina propria (below) are probably mast cells. $\times 550$.

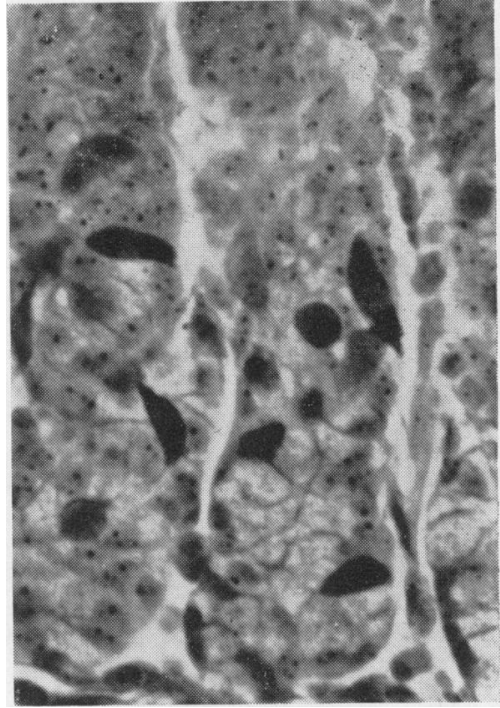

Fig. 3 Case 27: carcinoma of the stomach. Formalin-fixed tissue from region S1. Positive staining of $G$ cells with lead haematoxylin. Note also the strong staining of nucleoli in other cell types. $\times 420$.

considered by McGuigan (1968), using immunofluorescence, to be the $\mathrm{G}$ cell. This observation was completely confirmed by Bussolati and Pearse (1970), using sequential immunofluorescence and the Grimelius (1968) silver technique. It has now been shown to be the cell in human pyloric antrum which contains gastrin (Pearse and Bussolati, 1970).

When small pieces of antrum were incubated with L-DOPA, the $G$ cells were observed to take up and decarboxylate this compound. The product (dopamine) was demonstrated by formaldehyde-induced fluorescence (Fig. 4).

In thick $(0.5 \mu \mathrm{m})$ resin-embedded sections (Fig. 5) the G cell was easily found, appearing as a round or oval 'clear' cell in the majority of the mid-zone glands in the section. Figures 6, 7 , and 8 show different electron-microscopic appearances of the human $G$ cell. In Fig. 6, the two (clear) cells are almost completely devoid of granules (cf Capella, Solcia, and Vassallo, 1969). The cell on the left is observed to reach the gland lumen where it is furnished with microvilli, an observation first made by Solcia et al (1969b) in the guinea pig. Human G-cell granules have the same variability as those of other species (Vassallo et al, 1969; Solcia et al, 1969b; Forssmann et al, 1969) but they are considerably smaller (Table), being in all cases less than $200 \mathrm{~nm}$ in diameter.

There was no difficulty in establishing the identity of the enterochromaffin cell of the antrum and fundus. Staining positively by all silver techniques, including the Masson-Hamperl technique, the granules of this cell were also diazo- 


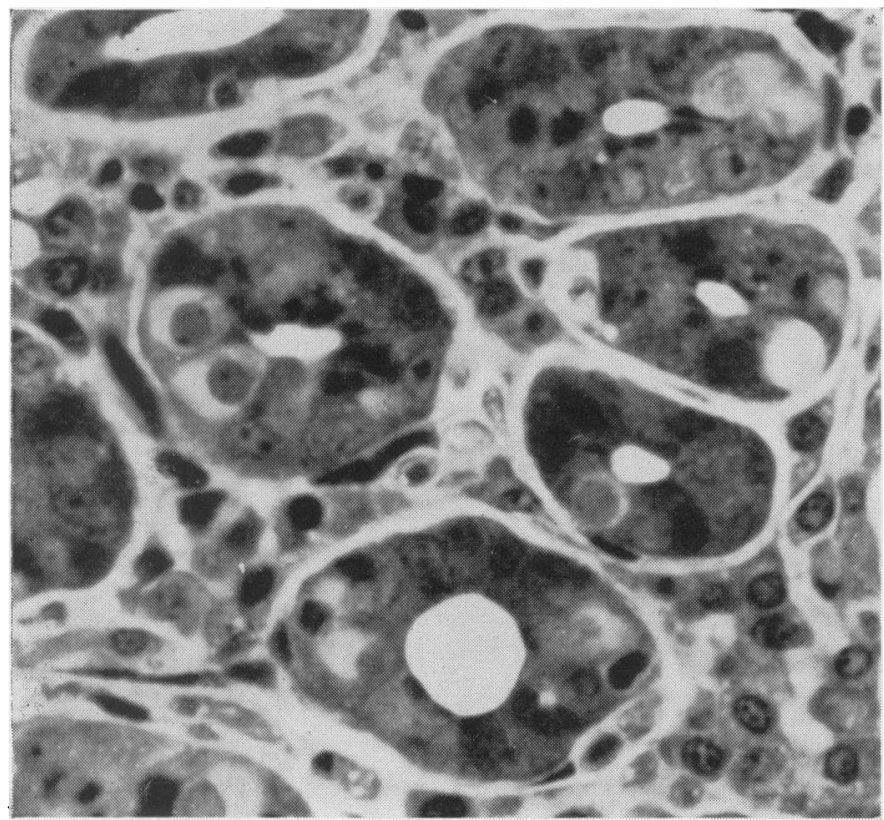

Fig. 5 Case 17: duodenal ulcer. Glutaraldehydeosmium fixed, resin-embedded $0.5 \mu \mathrm{m}$ section, stained with toluidine blue. Part of the middle zone of the pyloric glands from S1 region. Many (clear) $G$ cells can be distinguished. $\times 660$.

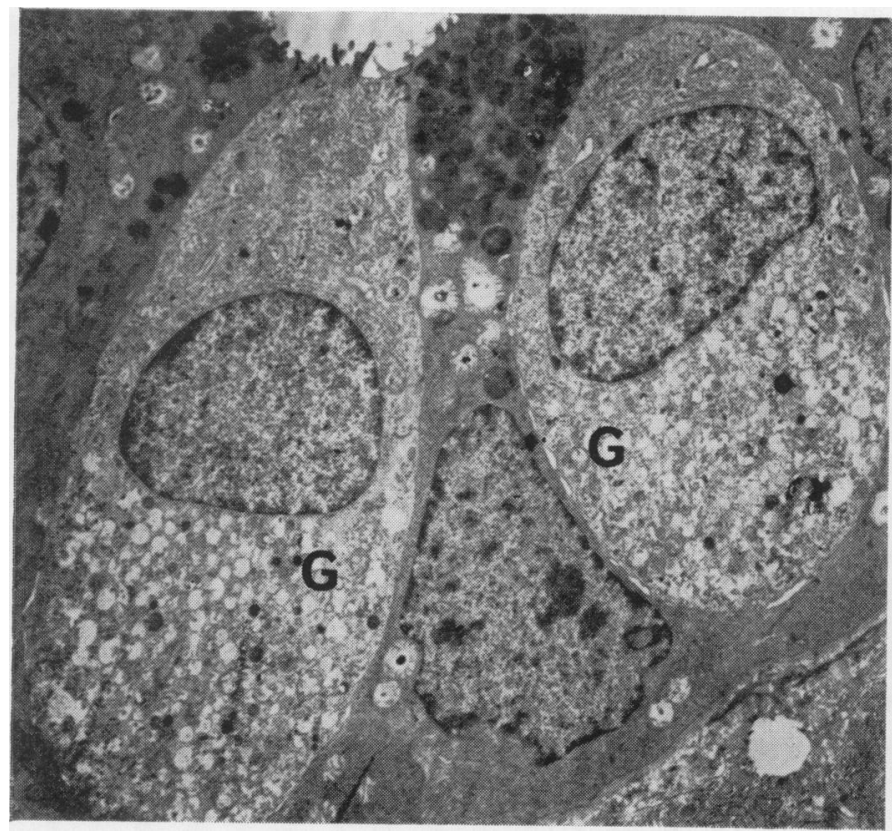

Fig. 6 Case 17 (as Fig. 4). This electron micrograph shows two adjacent partly discharged $G$ cells. The left-hand example is seen to reach the lumen of the gland where it possesses microvilli. $\times 4,200$.

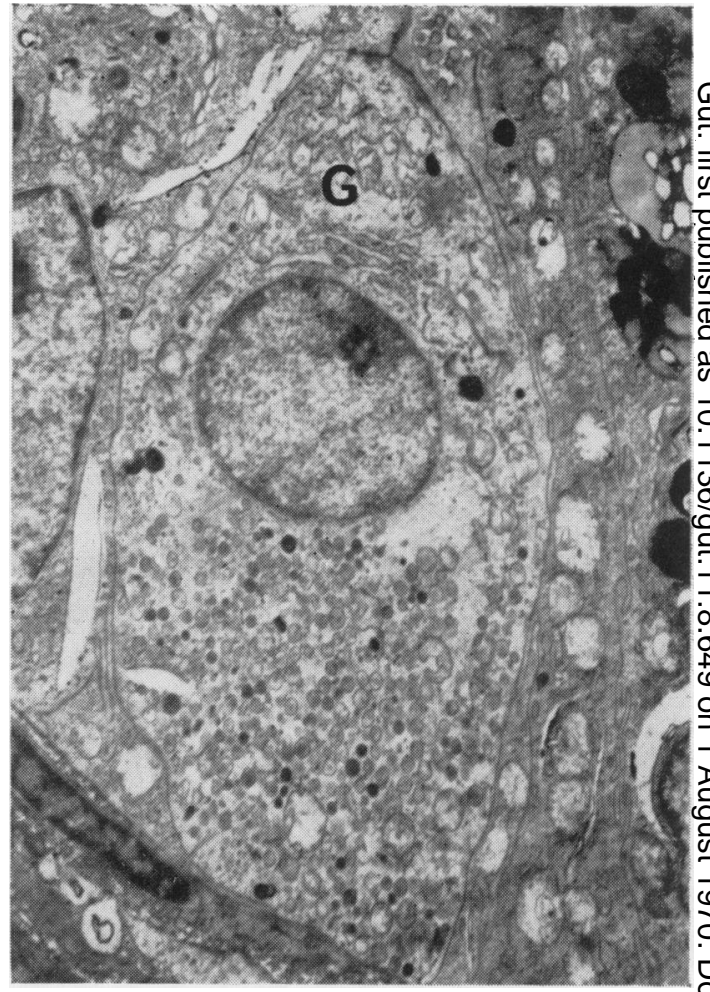

Fig. 7 Case 9: ectopic pancreas. A moderately well granulated $G$ cell from the $S 1$ region shows the characteristic variation in density of its storage granules which measure 100-150 nm. $\times 5,250$.

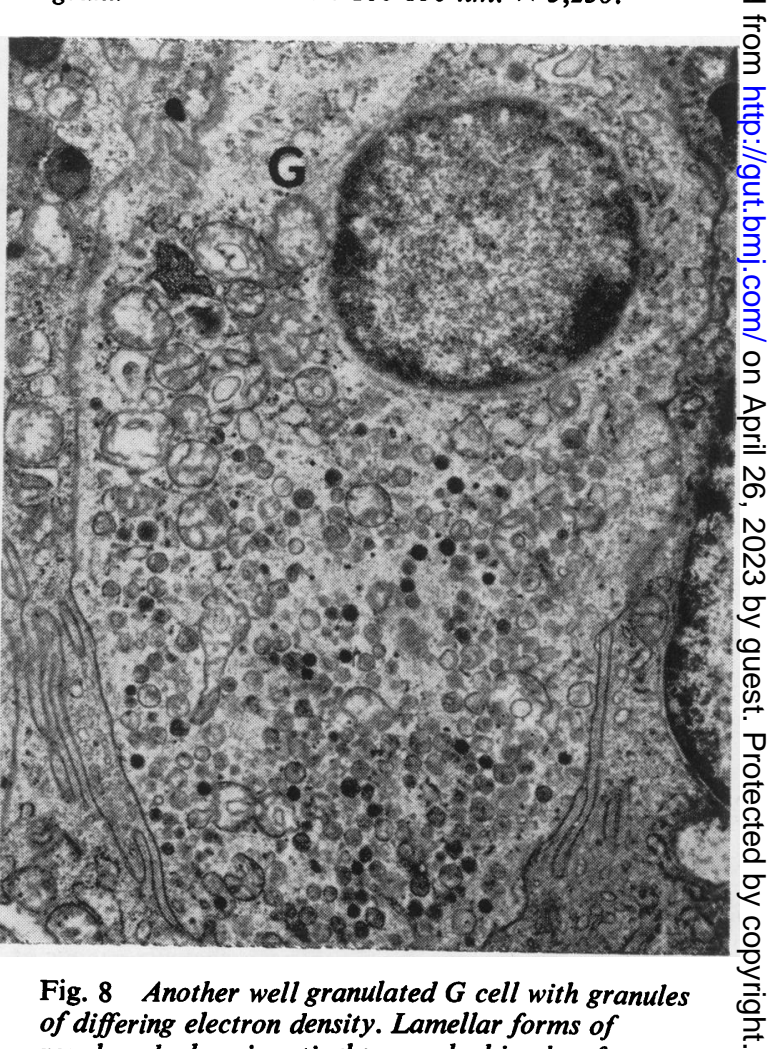




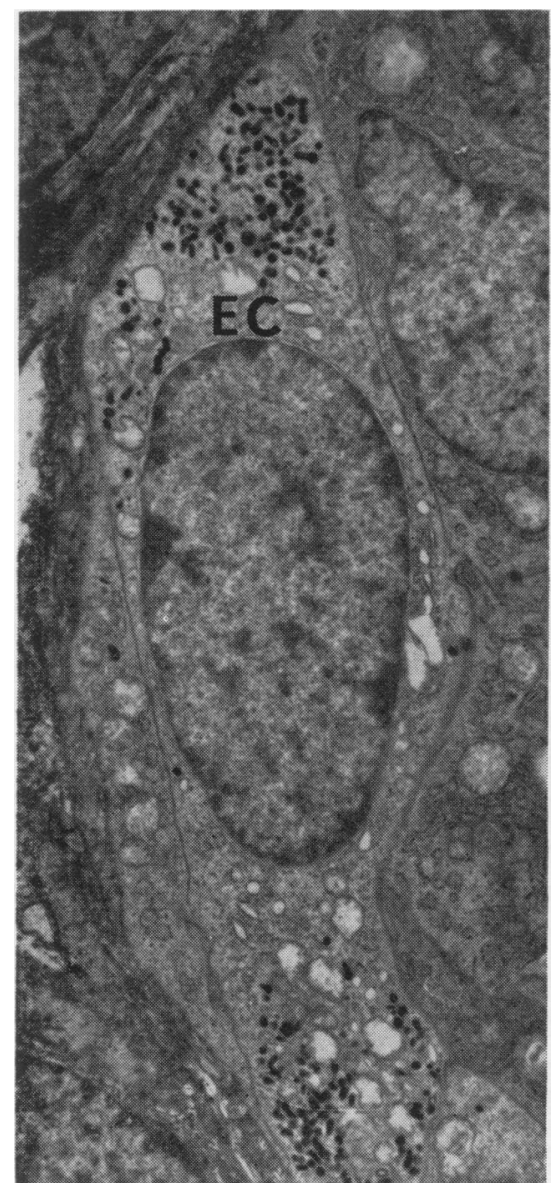

Fig. 9 Case 18: duodenal ulcer. $A$ well granulated enterochromaffin $(E C)$ cell from $S 1$ region. The characteristic polymorphic, very electron-dense, granules vary in size between 150 and $200 \mathrm{~nm} . \times$ 6,000 .

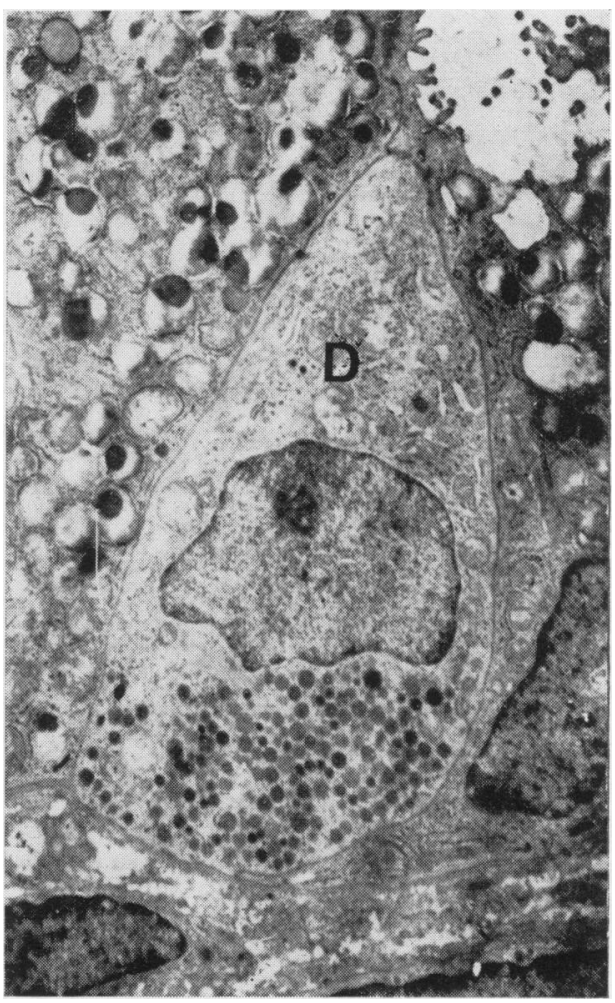

Fig. 10 Case 20: carcinoma of the common bile duct. A moderately well granulated D cell contains uniformly spherical secretion granules measuring up to $400 \mathrm{~nm}$ in diameter. $\times 5,250$.

Fig. 11 Case 18: duodenal ulcer. Part of a D cell from $S 5$ region shows secretory granules (average diameter $150 \mathrm{~nm}$ ) and a mass of microfilaments adjacent to the nucleus. The resemblance to Fig. 7 in Forssmann et al (1969) is extremely close. $\times 40,000$.

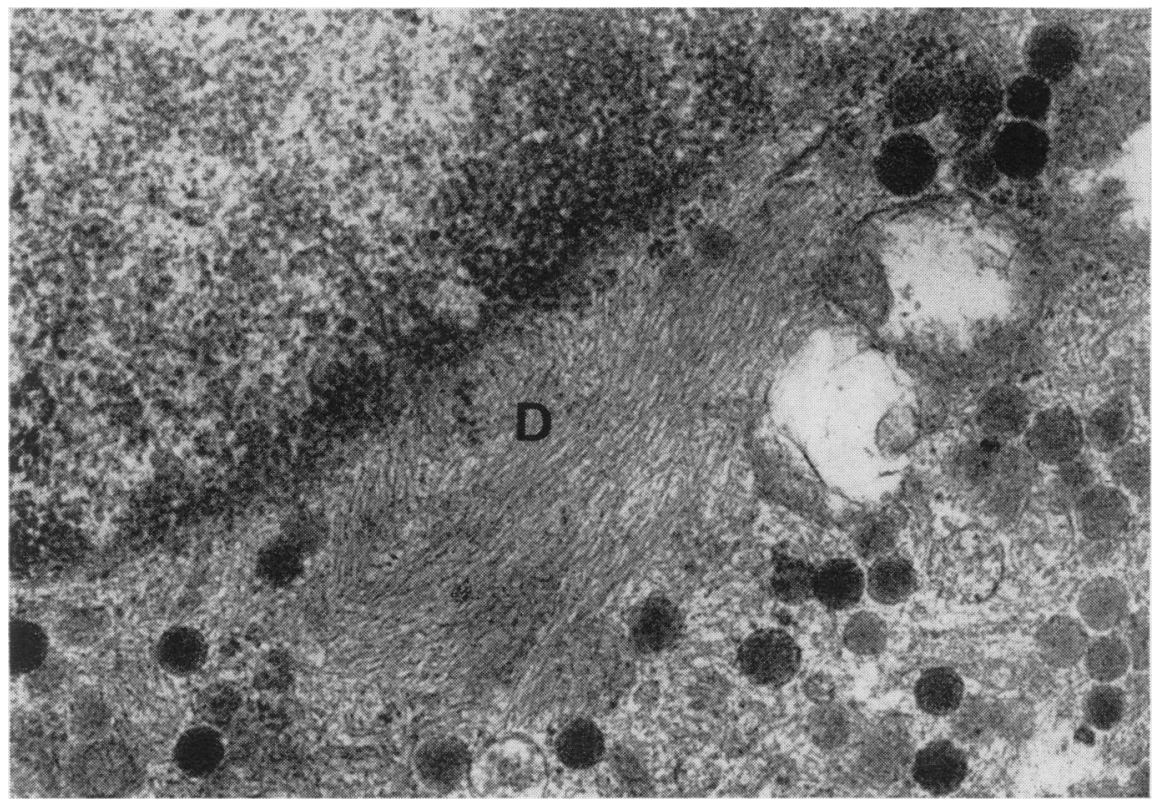

Fig. 11 


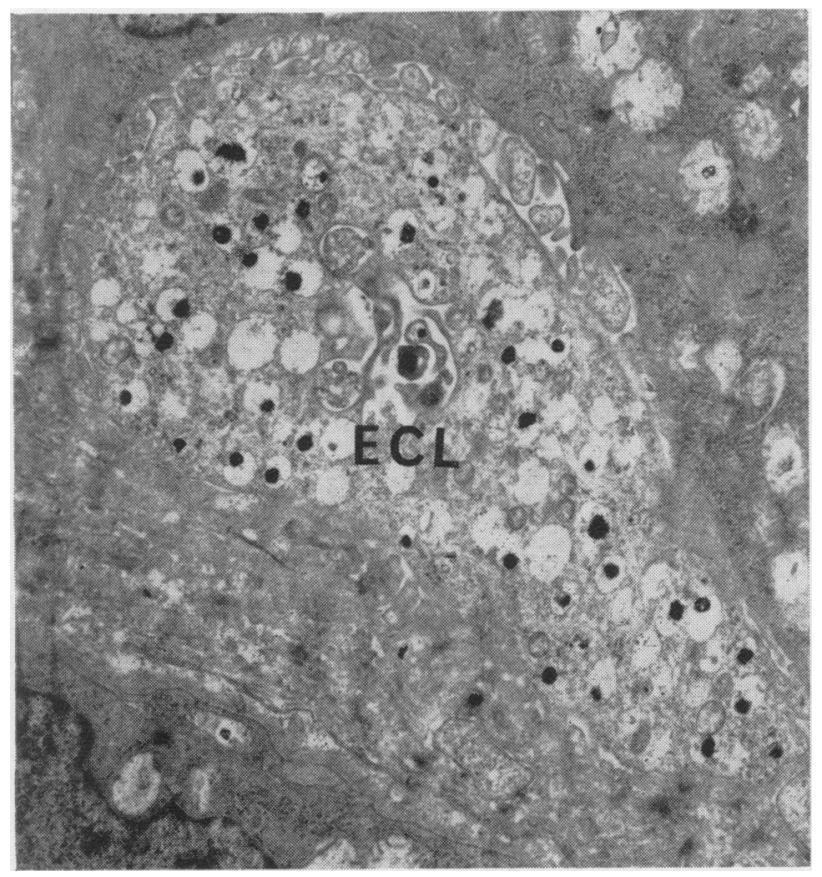

Fig. 12 Case 17: duodenal ulcer. Material from S1 region shows part of an EC-like (ECL) cell containing large vacuolated granules with dense cores. $\times 6,900$.

nium-positive, bright purple with toluidine blue after short acid treatment, and bright blue with $\mathrm{Pb}-\mathrm{H}$. They were situated mainly in the basal region of the glands but were scattered through the middle and upper layers as well. Their overall distribution was patchy. In swiss-roll preparations areas with very numerous enterochromaffin cells alternated with areas containing few or none. The characteristic electron microscopic appearance of the antral EC cell is shown in Figure 9. Its polymorphic electron-dense granules are situated at both ends of the cell. Invariably the granules are smaller than their counterparts in the duodenal mucosa $(200 \mathrm{~nm}$ on the shortest axis, as opposed to $400 \mathrm{~nm}$ in duodenal EC cells).

The second most numerous cell in the antrum, which was also present in large numbers in the fundic mucosa, was a bright purple metachromatic and $\mathrm{Pb}-\mathrm{H}$ positive cell. In swiss-roll preparations its overall localization was patchy, just as that of the EC cell. In some areas large clumps were found and in others none. In the electron microscope this cell is recognizable as a distinct type, the $\mathrm{D}$ cell (Fig. 10), containing much larger granules than the $G$ cell and having the 'nibbled-at' membrane of its granules and the microfilaments noted by Forssmann et al (1969). These two factors are shown in Figure 11.

The fourth cell type in the gastric mucosa we identified only by electron microscopy (Fig. 12), as the so-called EC-like (ECL) cell described by
Capella et al (1969). Like these authors, we found the ECL cell usually in the fundic regions $(\mathrm{S} 4,5,7)$ but occasionally in the pylorus $(\mathrm{S} 1,2,3)$. It bears a superficial resemblance to the pancreatic islet $\beta$-cell, though lacking the characteristic dense crystals in its membrane-limited vesicles.

\section{DUODENAL MUCOSA}

The most easily distinguishable endocrine poly- is peptide cell in the duodenal mucosa was the EC $\vec{\circ}$ cell (Fig. 13). It was not, however, the most numerous. Its cytochemical characteristics were those of the antral variety but the granules were, on the average, twice as large.

The most numerous cell in the duodenum, which was also found in Brunner's glands, was a cell of the type illustrated in Figures 14, 15 , and 16. Its characteristic granules, spherical and of rather even electron density, had an average diameter of $350 \mathrm{~nm}$. Because of the size of its granules the cell is referred to as the large granule $(\mathrm{Lg})$ cell, or simply as the $\mathrm{L}$ cell. It was highly metachromatic and stained positively with $\mathrm{Pb}-\mathrm{H}$; it was argyrophilic but not argentaffin, and diazonium-negative. Usually round or oval in shape, it sometimes appeared to be pyramidal, with its apex on the basement membrane. It was observed to reach the lumen on occasion (Fig. 16).

The third endocrine cell type in the duodenum was orthochromatic with toluidine blue after brief acid treatment. With the optical microscope its granulations were not apparent but in the electron microscope (Fig. 17) they were seen to be very small $(100-150 \mathrm{~nm})$, and of varying electron density. From this observation is derived the name small granule $(\mathrm{Sg})$, or simply, $\mathrm{S}$ cell. The ratio of the three endocrine cell types in the duodenum was EC: $L: S$ as $1: 4$ : $<1$, whereas in the jejunum it was EC : $\mathrm{S}: \mathrm{L}$ as $4: 1:<<1$.

\section{Discussion}

The fact that there are discrepancies in the Table is hardly surprising. It is based on studies carried out in three different localities on at least $\mathscr{C}$ six species (cat, dog, rabbit, guinea-pig, rat, man). It is perhaps more surprising that there is a large measure of agreement.

The term enterochromaffin-like is used by Scandinavian authors, following its original $\stackrel{D}{\overparen{D}}$ use by Håkanson and Owman (1967) to mean a $\varrho$ cell, normally containing histamine, which takes up and decarboxylates L-DOPA or L-5-hydro- 8 xytryptophan (5-HTP). It has not been shown that the enterochromaffin-like cells, as described here, have this characteristic. In the fundus of rat stomach Penttilä and Hirvonen (1969) have 

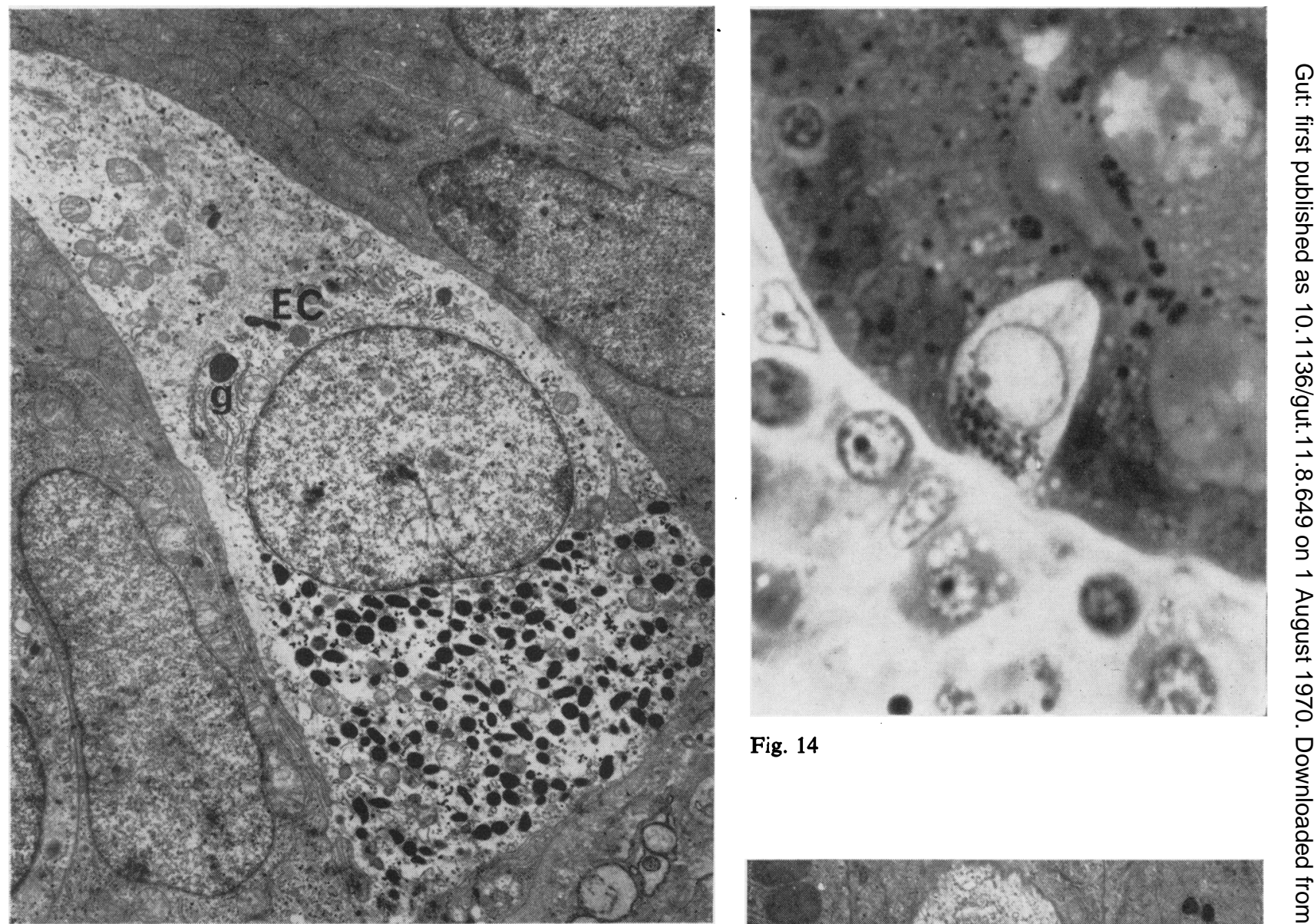

Fig. 13

Fig. 14

Fig. 13 Case 26: duodenal ulcer. A typical basigranular enterochromaffin $(E C)$ cell with very electron-dense, polymorphic granules. These measure up to $400 \mathrm{~nm}$ on their shortest axis. Note Golgi region $(g)$ between the apical pole and the nucleus. $\times 6,000$.

Fig. 14 Case 20: a 'thick' resin-embedded section, stained with toluidine blue, from region $D 2$, shows a single large granule $(L g)$ cell. $\times 1,648$.

Fig. 15 Case 25: cholelithiasis. A well granulated cell $(\mathrm{Lg})$ from $\mathrm{D} 2$ region of duodenum. These granules are spherical, measure up to $400 \mathrm{~nm}$ diameter, and have relatively even electron density. $\times 6,000$.

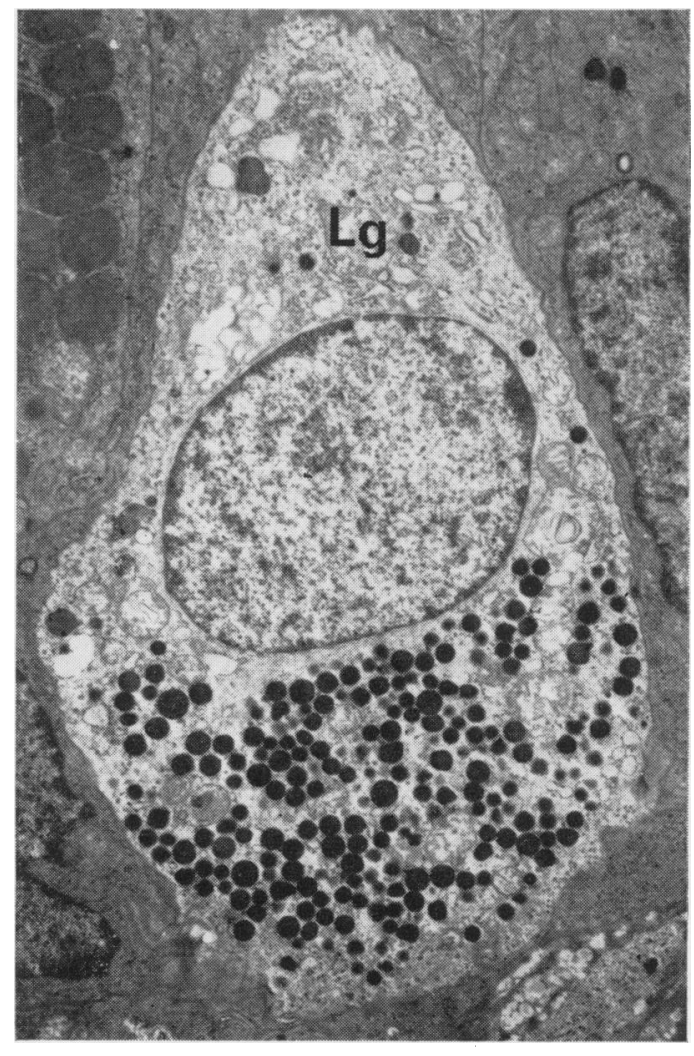




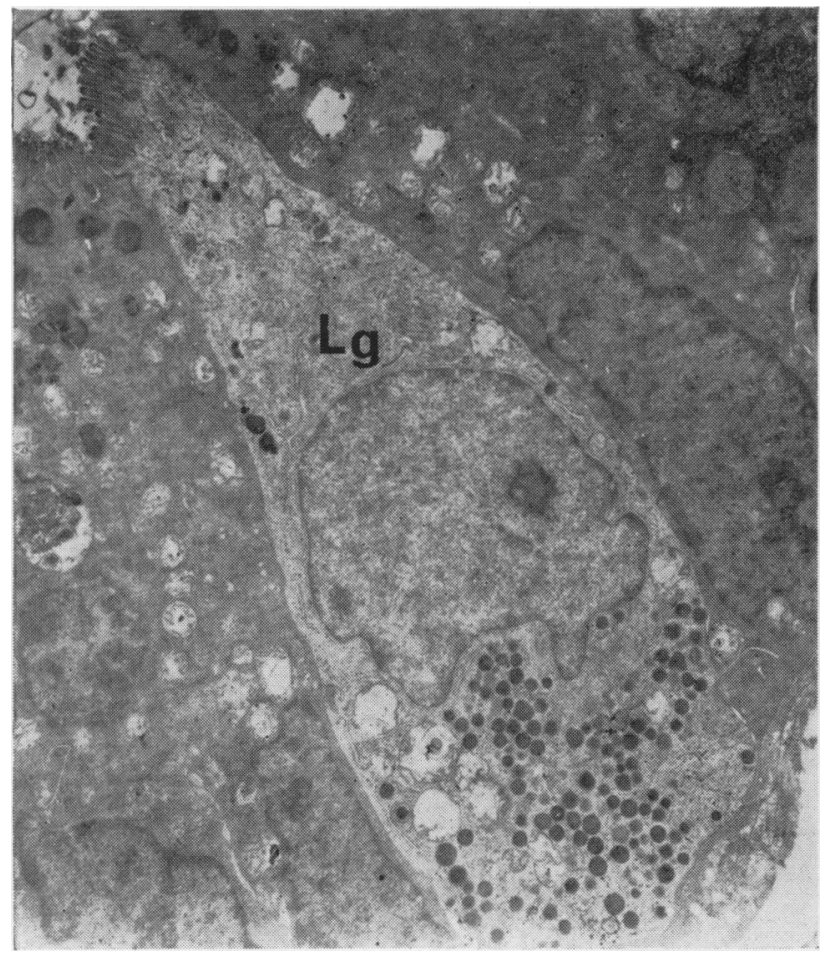

Fig. 16 Case 21. A large granule $(\mathrm{Lg})$ cell with basal granules reaches the lumen and possesses microvilli. $\times 5,400$.

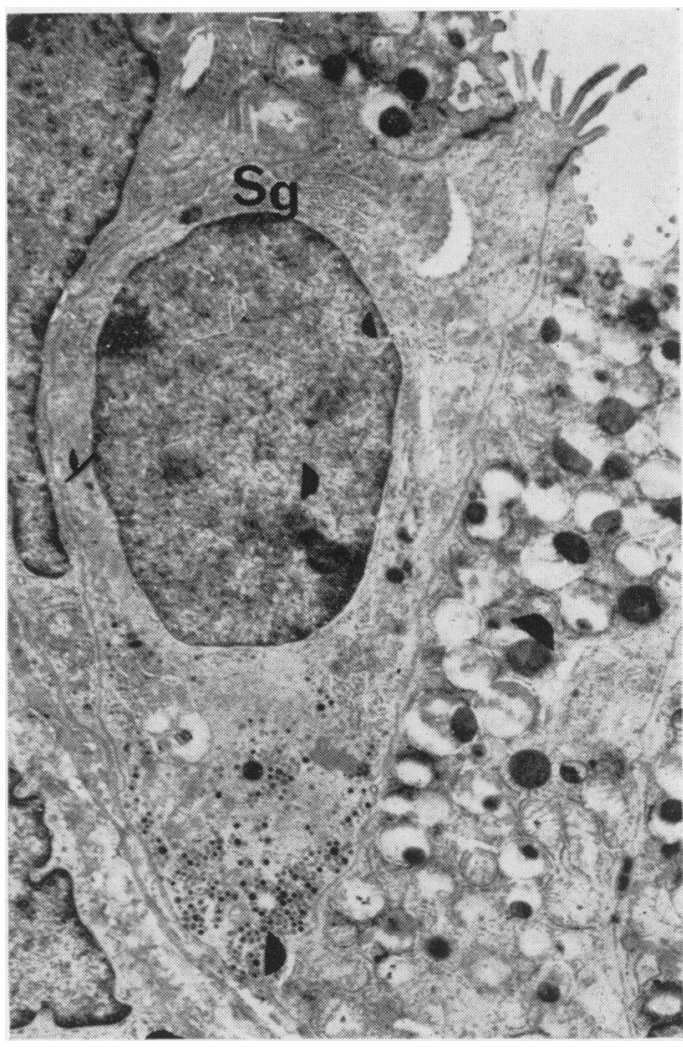

Fig. 17 Case 20. Cell from region listed as S1, situated in the same pyloric gland as the cell illustrated in Figure 9, with its base towards the lumen and its apex towards the basement membrane, is a typical Sg cell which belongs to the duodenal micosa. $\times 5,250$.

\begin{tabular}{|c|c|c|c|c|c|c|c|}
\hline \multirow[t]{2}{*}{ Site } & \multicolumn{4}{|c|}{ Terminology } & \multirow[t]{2}{*}{ Equivalent in Pancreas } & \multirow[t]{2}{*}{ Product } & \multirow[t]{2}{*}{ Granule Size $(\mathrm{nm})$} \\
\hline & Pavia & London & Geneva & Wiesbaden & & & \\
\hline \multirow[t]{5}{*}{ Stomach } & EC & EC (diazonium) & I enteroserotonin & EC & EC & (Incretin) & $\begin{array}{l}\text { 200-250 (Pavia) } \\
240 \text { (London) }\end{array}$ \\
\hline & G & RO & $\mathbf{V}$ & G & - & Gastrin & $\begin{array}{l}\text { Av } 290 \text { (Pavia) } \\
300-350 \text { (Geneva) } \\
180 \text { (London) }\end{array}$ \\
\hline & $\mathbf{x}$ & ND & III $^{2}$, D-like & $\mathbf{D}$ & D & - & $\begin{array}{l}150-500 \text { (Pavia) } \\
500-700 \text { (Gevena) } \\
A v 350 \text { (London) }\end{array}$ \\
\hline & ECL & $\begin{array}{l}\text { (Identified by electron } \\
\text { microscopy only) }\end{array}$ & I variant & ECL & - & - & $\begin{array}{l}300-350 \text { and core } 100 \text { (Pavia) } \\
300-800 \text { (Geneva) }\end{array}$ \\
\hline & - & Not in man & $\begin{array}{l}\text { II } \\
\mathbf{A}\end{array}$ & $\mathbf{A}$ & $\mathbf{A}$ & - & $510-250$ (Geneva) \\
\hline \multirow[t]{3}{*}{ Intestine } & $\mathbf{L}$ & $\begin{array}{l}\text { Argyrophilic and } \\
\text { metachromatic }\end{array}$ & Mast cell & Lg or $\mathbf{L}$ & $\mathbf{A}$ & (Secretin) & $\begin{array}{l}300-400 \text { (Pavia) } \\
500-700 \text { (Geneva) } \\
350 \text { (London) }\end{array}$ \\
\hline & $\mathbf{S}$ & $\begin{array}{l}\text { Argyrophilic and } \\
\text { orthochromatic }\end{array}$ & II & $\mathrm{Sg}$ or $\mathrm{S}$ & $\begin{array}{l}\mathbf{A} \\
\mathbf{D}\end{array}$ & $\begin{array}{l}\text { (Cholecystokin- } \\
\text { pancreozymin) }\end{array}$ & $\begin{array}{l}200 \text { (Pavia) } \\
150-250 \text { (Geneva) } \\
100-150 \text { (London) }\end{array}$ \\
\hline & EC & EC (diazonium) & I enteroserotonin & EC & EC & (Incretin) & 350 (Pavia) \\
\hline
\end{tabular}

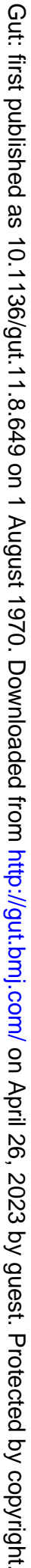

Table Comparative nomenclature 
shown DOPA uptake and decarboxylation by the parietal cell and they therefore equate this cell with the enterochromaffin-like cell. The presence of dopamine in their parietal cells is not to be doubted. The possibility of decarboxylation of DOPA taking place elsewhere than in the parietal cell has still to be considered. In the pylorus of man and of all other species we have so far examined (dog, guinea pig, mouse, rat, hamster), it is the $G$ and $D$ cells which take up and decarboxylate L-DOPA. Parietal cells are in any case not present in the antrum.

The $\mathbf{G}$ cell is easily distinguished, as a clear cell, in conventionally stained preparations of human antrum. It requires the electron microscope to establish its connexion with the lumen of the gland. This is observed with such frequency, in what are necessarily random samples, that it may be assumed to be the normal state. The significance of this is that the $G$ cell requires no nervous relay in order to respond to changes in luminal $p \mathrm{H}$ or to alterations in the concentration of any particular constituent of the luminal contents.

The D cell of the human gastric mucosa, and the $D$ and $A$ cells in animals, are named for the pancreatic islet cells which they resemble ultrastructurally. Sutherland and de Duve (1948) first suggested that the argyrophil cells of the gastric mucosa should be regarded as counterparts of the pancreatic A cells, and Davis (1954) pointed out that the latter shared similar staining characteristics with certain gastric mucosal cells, which he called $X$ cells. The $X$ cells, however, were unaffected by synthalin which produced hydropic degeneration of the A cells. The relationship of the human D cell to the 'undifferentiated cell', found by Johnson and Young (1968) in dog stomach fundus, is not clear.

The human $\mathrm{G}$ cell population shows consider- able variation between one case and another and, since normal stomachs were not available for study, these differences have to be interpreted with caution. Solcia et al (1969b) noted an increase of argyrophil-metachromatic cells in cases of duodenal ulcer and hypersecretion, but we found it difficult to be certain of this in view of the great individual variation shown by our cases. If a feed back mechanism (acid inhibition) is operating in cases with high acid secretion (and low serum gastrin levels) one would expect increased granularity of the $\mathrm{G}$ cells, and possibly an increase in their size, but not necessarily a numerical increase. In carcinoma cases with low secretion (and possibly high levels of serum gastrin) one might expect hyperplasia and degranulation of the $G$ cells. This we did not find. On the contrary, in carcinoma cases the $G$ cells were large, round, or oval in shape, and fully granulated (masked metachromasia technique). In duodenal ulcer cases the $G$ cells were certainly very numerous (possible hyperplasia) but invariably poorly granulated (masked metachromasia technique) and therefore less easily distinguished.

In the stomach there are four endocrine cell types, one of which has been identified with a known hormone. In the duodenum and jejunum there are three endocrine polypeptide cells and at least four possible hormones (secretin, incretin, cholecystokinin-pancreozymin, and enterogastrone) but no firm identification of one with the other. Orci, Pictet, Forssmann, Renold, and Rouiller (1968) suggested that their A-like cells of the intestine (the $L$ cells of this paper) were responsible for the production of enteroglucagon. The latter is presumably to be equated with glucagon-like immunoreactivity which is present in both duodenum and jejunum (Ungar, Ohneda, Valverde, Einsentraut, and Exton, 1968). In the

\begin{tabular}{|c|c|c|c|c|c|c|c|c|}
\hline \multirow[t]{3}{*}{ Cell Type } & \multirow{3}{*}{$\begin{array}{l}\text { Masked } \\
\text { Metachromasia }\end{array}$} & \multicolumn{7}{|l|}{ Techniques } \\
\hline & & \multirow{2}{*}{$\begin{array}{l}\text { Lead- } \\
\text { hxematoxylin }\end{array}$} & \multicolumn{5}{|l|}{ Silver } & \multirow[t]{2}{*}{ Xanthydrol (post GA) } \\
\hline & & & Davenport & $S e v-M$ & Bodian & Grimelius & Masson-Hamperl & \\
\hline EC & $\begin{array}{l}+ \\
\text { Blue } \\
\text { Violet }\end{array}$ & + & + & + & + & + & + & + \\
\hline G & $\stackrel{+}{\text { Red }}$ & + & + & - & - & + & - & - \\
\hline D & $\begin{array}{l}++ \\
\text { Red } \\
\text { s } \mathbf{H C l} \text { purple }\end{array}$ & $x-$ & -- & - & - & - & - & - \\
\hline ECL & - & + & - & + & - & - & - & $\stackrel{+}{\text { Violet }}$ \\
\hline $\mathbf{A}$ & $\begin{array}{l}+ \\
\text { Red } \\
\text { Violet }\end{array}$ & - & + & $?$ & + & - & $x-$ & - \\
\hline $\begin{array}{l}\mathbf{L} \\
\mathbf{S}\end{array}$ & $\begin{array}{l}++ \\
\text { Red } \\
+\end{array}$ & + & + & $?$ & $?$ & + & - & + \\
\hline $\mathrm{EC}$ & $\begin{array}{l}\text { Blue } \\
++ \\
\text { Purple }\end{array}$ & $\begin{array}{l}? \\
+\end{array}$ & $\begin{array}{l}+ \\
+\end{array}$ & $\begin{array}{l}- \\
+\end{array}$ & $\begin{array}{l}- \\
+\end{array}$ & $\begin{array}{l}- \\
+\end{array}$ & $\begin{array}{l}- \\
+\end{array}$ & $\begin{array}{l}- \\
+\end{array}$ \\
\hline
\end{tabular}


cat intestine, according to Vassallo et al (1969), the distribution of the $\mathrm{S}$ cell was comparable to that of secretin (mainly duodenal). They related their $\mathbf{L}$ cell to the production of cholecystokinin-pancreozymin. In human duodenum it is clearly the $\mathrm{L}$ cell which predominates and and on the basis of its resemblance to the pancreatic A cell, and of the close structural relationships between glucagon and secretin, a case can be made out for connecting it with secretin production. This would leave the $S$ cell as responsible forcholecystokinin-pancreozymin, and the enterochromaffin cell, possibly, for incretin. (In the Table these hormones are shown in brackets to indicate complete lack of credible evidence for these hypotheses.)

It is of interest to note that both the $\mathrm{L}$ cell and the $\mathbf{S}$ cell are observed to reach the gland lumen, where they are provided with microvilli. Once again, therefore, a direct response to changes in the concentration of specific components of the intestinal contents is possible.

We feel that, having established a base-line with our studies on roll preparations, it will be possible, in future, to interpret results derived from suction biopsies with a greater degree of confidence. This will require no lesser degree of caution, in view of the patchy distribution observed for all types of endocrine polypeptide cells.

We thank Mr A. Cox and Mr A. K. Monro (Hammersmith Hospital), and Mr Rodney Smith (St George's Hospital) for providing us with material from their cases. Grants from the Wellcome Trust and Medical Research Council for research on endocrine polypeptide cells are gratefully acknowledged.

\section{References}

Bussolati, C., and Pearse, A. G. E. (1970). Immunofluorescent localization of the gastrin-secreting $G$ cell in the pyloric antrum of the pig. Histochemie, 21, 1-4.

Capella, C., Solcia, E., and Vassallo, G. (1969). Identification of six types of endocrine cells in the gastrointestinal mucosa of the rabbit. Arch. histol. jap., 30, 479-495.
Davis, J. C. (1954). The relation between the pancreatic alpha cells and certain cells in the gastric mucosa. J. Path. Bact. $67,237-240$.

Forssmann, W. G., Orci, L., Pictet, R., Renold, A. E., and Rouiller, C. (1969). The endocrine cells in the epithelium of the gastrointestinal mucosa of the rat. J. Cell Biol., 40, 692-715.

Grimelius, L. (1968). A silver nitrate stain for $a_{2}$ cells in human $\tilde{\omega}^{+}$ pancreatic islets. Acta Soc. Med. upsalien, 273, 243-270

Håkanson, R., Lilja, B., and Owman, C. (1969). Cellular localio zation of histamine and monoamines in the gastric mucose of man. Histochemie, 18, 74-86.

Håkanson, R., and Owman, C. (1967). Concomitant histo chemical demonstration of histamine and catecholamines in enterochromaffin-like cells of the gastric mucosa. Lifes Sci., 6, 759-766.

Hellerstrom, C., and Hellman, B. (1960). Some aspects of silve $\vec{P}$ impregnation of the islets of Langerhans in the rat: Acta endocr. (Kbh.), 35, 518-532.

Johnson, F. R., and Young, B. A. (1968). Undifferentiated cell in gastric mucosa. J. Anat. (Lond.), 102, 541-551.

McGuigan, J. E. (1968). Gastric mucosal intracellular localiza tion of gastrin by immuncfluorescence. Gastroenterology,55, 315-327.

Orci, L., Pictet, R., Forssmann, W. G., Renold, A. E., and Rouiller, C. (1968). Strustural evidence for glucagoron producing cells in the intestinal mucosa of the rat. Diabetol $\frac{\overrightarrow{0}}{6}$ ogia, 4, 56-67.

Pearse, A. G. E. (1960). Hıstochemistry, Theoretical and Applied $\frac{\mathrm{O}}{\square}$ 2nd ed. Churchill, London.

Pearse, A. G. E., and Bussolati, G. (1970). Immunofluorescenca studies of gastrin cell distribution in different clinica states. Gut, 11, 646-648.

Penttilä, A., and Hirvonen, J. (1969). Identity of the basallste located parietal and enterochromaffin-like cells of the raf gastric mucosa. Scand. J. Gastroent., 4, 489-496.

Solcia, E., Capella, C., and Vassallo, G. (1969a). Lead-haematoxylin as a stain for endocrine cells. Histochemie, 20, 116-126.

Solcia, E., Vassallo, G., and Capella, C. (1968a). Selectivo staining of endocrine cells by basic dyes after acid hydro lysis. Stain Technol., 43, 257-263.

Solcia, E., Vassallo, G., and Capella, C. (1969b). Studies on the $G$ cells of the pyloric mucosa, the probable site of gastrino secretion .Gut, 10, 379-388.

Solcia, E., Vassallo, G., and Sampietro, R. (1967). Endocrine cells in the antro-pyloric mucosa of the stomach. $Z \vec{O}$ Zellforsch., 81, 474-486.

Solcia, E., Vassallo, G., and Sampietro, R. (1968b). Studies onendocrine cells of the pyloric mucosa as possible site of gastrin production. In Procedings of VIIIth Internationa? Congress of Gastroenterology, pp. 110-111. Schattauer Stuttgart.

Sutherland, E. W., and Duve, C. de (1948). Origin and distri bution of the hyperglycemic-glycogenolytic factor of the pancreas. J. biol. Chem., 175, 663-674.

Unger, R. H., Ohneda, A., Valverde, I., Einsentraut, A. M., andi Exton, J. (1968). Characterization of the responses of circulating glucagon-like immunoreactivity to intra duodenal and intravenous administration of glucose. 0 J. clin. Invest., 47, 48-65.

Vassallo, G., Solcia, E., and Capella, C. (1969). Light and elec-D tron mizroscopic identification of several types of endo-음 crine cells in the gastrointestinal mucosa of the cat. $Z$. Zellforsch., 98, 333-356. 